\title{
Effectiveness of Audit Committees: Evidence from Listed Companies in Sri Lanka
}

\author{
P.T.M. Gunathilake ${ }^{1 *}$ M. Ranasinghe ${ }^{2}$ \\ ${ }^{1}$ Department of Business Finance, Faculty of Management, \\ University of Peradeniya, Sri Lanka. \\ ${ }^{2}$ Department of Management Studies, Faculty of Management, \\ University of Peradeniya, Sri Lanka. \\ "Corresponding author: madushanigunathilake@gmail.com
}

Received: 17 April 2018

Accepted: 15 October 2018

\begin{abstract}
Audit Committee has become a very effective mechanism for ensuring governance of companies. However, despite its increasing importance, examining its effectiveness within the listed companies in Sri Lanka remains under studied. Therefore, this study aims to conduct an investigation into the audit committee practices and its effectiveness in relation to the listed companies in Sri Lanka, i.e., from the perspective of a developing economy. Further, the study investigates the impact of audit committee attributes on the effectiveness of audit committees. This study followed a quantitative research design in gleaning opinion on the research problem and attaining research objectives of the study. A questionnaire survey was used in gathering data from Board of Directors of 30 companies listed on the Colombo Stock Exchange. Current state of audit committee practices and their effectiveness have been analyzed using frequency distributions. Multiple regression analysis and correlation analysis have been used to investigate the relationship between audit committee attributes and effectiveness of audit committees. The results demonstrated that audit committee practices and effectiveness of listed companies in Sri Lanka are perceived to be at a satisfactory level. Regression results also revealed that knowledge and experience of the audit committee members have positive impact on the effectiveness of audit committees. Moreover, correlation analysis suggested that independence and meetings of audit committees have strong positive correlations with the effectiveness of audit committees.
\end{abstract}

Peradeniya Management Review - Vol. I , No.01 , (June)2018 
Keywords: Audit Committee, Audit committee attributes, Effectiveness of audit committee

\section{Introduction}

Audit Committee is one of the key mechanisms within the governance structure of listed companies (Genron and Bedard, 2006; Turley and Zaman, 2007; Sori, Hamid, Saad and Evans, 2007; Osma and Noguer, 2007 and Mallin, 2010). A growing number of recent studies (e.g., Chen, Duh and Shiue, 2008 and Beasley, Carcello, Hermanson and Neal, 2009) also placed a heavy emphasis on the role of an audit committee in strengthening overall corporate governance practices. Further, the audit committee builds a link among the company's management, the board of directors and the internal and external auditors. Burke and Guy (2002) and the Sarbanes - Oxley Act (2002) have mentioned the audit committee as a sub - committee of the Board of Directors charged with overseeing the integrity of the financial reporting process.

The origin and further evolvement of audit committees under the corporate governance took place predominantly in developed countries including the U.S.A. and the U.K. Further, many governments made incremental alterations to their financial markets' corporate governance requirements (OECD, 2009, Kirkpatrick, 2009). Hence, much of the literature has focused on audit committees in developed countries. However, studies on audit committees are scarce in developing economies such as in Sri Lanka.

With the introduction of open economic policies in 1977, the private sector has become a driving force of the Sri Lankan economy. As a result, there had been a significant growth in the corporate sector, particularly in public listed companies. In this context, corporate governance is a vital issue and an important factor for economic development owing to its contribution on increasing investors' confidence, protecting stock markets, preventing company failures and facing regional economic crisis.

Some major steps have been undertaken in Sri Lanka to uplift and stabilize good governance within companies from 1997 to 2013. Further, the Colombo Stock 
Exchange mandated the guidelines for corporate governance effective from $1^{\text {st }}$ April 2008. The audit committees play a pivotal role on most of the voluntary and mandatory corporate governance guidelines and practices in Sri Lanka. Although the audit committee has been widely recognized as a very effective mechanism for ensuring good governance in corporate affairs, there has been limited research that specifically focuses on audit committee practices and effectiveness. Further, the concepts of audit committee practices, attributes, roles and responsibilities in Sri Lankan companies remain to be studied. Therefore, the statement of problem of the study can be presented as "What are the factors affecting the effectiveness of audit committees of listed companies in Sri Lanka?"

Pomeranz (1997) and Bedard and Gendron (2010) drove home the fact that very little is known about the actual practices of audit committees and the majority of audit committee studies have been conducted in the context of developed countries including the U.S.A., the U.K., Canada and Australia. The area of audit committee practices and effectiveness in emerging economies is still underresearched.

Accordingly, the objectives of the study are two - fold as indicated below:

- To examine and evaluate the current audit committee practices and effectiveness of the listed companies in Sri Lanka, and

- To investigate the factors contributing to the effectiveness of audit committees of the listed companies in Sri Lanka.

\section{Literature Review}

A number of researches including Mohiuddin and Karbhari (2010) have pinpointed that the audit committee attributes, namely independence, expertise, diligence, authority and resources and meetings, have important impacts on carrying out audit committee roles successfully. Audit committee composition is a key factor and the committee's independence has been described as a pre-requisite of its effectiveness (Abbott et al., 2007, Berard and Gendron, 2010). Hence, audit committees should be independent of the organization's management in order to perform an oversight role and to protect 
the shareholders' interests. Positive relationship between members' financial knowledge and effectiveness of audit committees has been found in many studies (Treadway Commission, 1987; DeZoort et al., 2001; Felo et al., 2003 and Defond et al., 2005). The above discussion explicitly argues that audit committee members should have relevant expertise for performing the committee's roles effectively. Further, authority and resources are two pivotal factors for an effective audit committee. Most audit committee guidelines (viz. the Treadway Report, 1987, the Cadbury Committee, 1992, the BRC, 1999, the Sarbanes- Oxley Act, 2002, the Combined Code, 1999, 2003) recommend that the audit committee should be provided with sufficient authority and resources for their effective functioning. Kalbers and Fogarty (1993) have stated that audit committee members' diligence is one of the main components for its effectiveness. Moreover, Share et al. (2009) have highlighted that members' diligence is very important in performing the responsibilities of an audit committee effectively and with integrity. Prior studies (e.g., McMullen, 1996; Collier and Gregory, 1998 and ICAEW, 2001) have reported the impotence of audit committee meetings on effectiveness of audit committees.

Rittenberg and Nair (1994) and Mendez and Garcia (2007) have mentioned that the mere existence of an audit committee alone does not provide sufficient control, nor does it ensure that the company will maintain a high standard of financial integrity. A large number of studies focused on effectiveness of audit committees (for instance, Jenkins and Robinson, 1985; Kalbers, 1992a; Kalbers and Fogarty, 1993; Rittenberg and Nair, 1994; Poter and Gendall, 1998; Millstenin, 1999; Raghunandan et al., 2001 and Smath, 2003) have interpreted the word "effectiveness" as "carrying out or fulfilling its specific oversight responsibilities or duties". Further, various studies have used "discharging their oversight responsibilities" for the interpretation of effectiveness of audit committees (Braiotta, 1986, Verschoor, 1989, Lee and Stone, 1997, Turley and Zaman, 2002, Watts, 2002, Zain and Subramaniam, 2007). According to Dezoort (1998), effectiveness of audit committee is "a committee's collective ability to meet its oversight objectives". Further, according to DeZoort et al. (2002) "an effective audit committee has qualified members with the authority and 
resources to protect shareholders' interest by ensuring reliable financial reporting, internal controls, and risk management through its diligent oversight efforts". Furthermore, DeZoort et al. (2002) have developed a framework with four fundamental determinants of effectiveness of audit committees, namely composition, authority, resources, and diligence. On the other hand, instead of focusing on the determinants of effectiveness of audit committees, Kalbers and Fogarty (1993) and Turley and Zaman (2004) analyzed the effectiveness of audit committees using a framework which focused on successfully performing audit committee roles. Mohiuddin and Karbhari (2010) have also highlighted that effectiveness of audit committees mainly depends on the ability and scope of performing its oversight roles and responsibilities delegated by the board as developing the effectiveness of audit committees model.

According to the empirical studies and findings, it can be concluded that the audit committee attributes have important impacts on the effectiveness of audit committee and effectiveness of audit committees mainly depends on the achievement of audit committee roles and responsibilities. Therefore, the current study aims to investigate effectiveness of audit committees considering all these criteria namely audit committee attributes and audit committee roles and responsibilities.

Based on the literature as discussed above, the conceptual framework as shown in Figure 1 is developed to examine the effectiveness of audit committees. Accordingly, the study investigated the impact of input factors with regard to audit committee, viz. independence, knowledge and experience, authority and resource, diligence, and meetings, on the effectiveness of audit committees. 


\begin{tabular}{|l|l|}
\hline $\begin{array}{l}\text { Audit Committee } \\
\text { Attributes }\end{array}$ & $\begin{array}{c}\text { Audit Committee Effectiveness } \\
\text { Independence } \\
\text { Achieving Roles and } \\
\text { Responsibilities } \\
\text { Experience } \\
\text { Authority and } \\
\text { Resources }\end{array}$ \\
Diligence & Financial Reporting \\
Meetings & External Auditing \\
\hline
\end{tabular}

Figure 1: Conceptual Framework

\section{Methodology}

This study used quantitative research methods in gleaning opinion on the research problem and attaining research objectives of the study. A mailed questionnaire survey was employed with a questionnaire including twenty seven Five-Point Likert Scale questions where the lowest value of " 1 " indicating that the respondent strongly disagrees to any particular factor/statement and the highest value of " 5 " indicating that the respondent strongly agrees to the particular factor/statement in the actual practices in the company.

The population of this study was 287 companies listed on the Colombo Stock Exchange as at $31^{\text {st }}$ March 2013. Sample was not based on one industry sector in order to maintain the randomness of data. The initial sample was randomly selected 80 companies and copies of questionnaire were mailed to the audit committee members from November 2013 to January 2014. However, 30 companies were selected for the final sample due to the poor response rate. Sample size is 10.45 percent of the total population of 287 listed companies.

Based on the model developed to examine the effectiveness of audit committees (Figure 1), the concepts and variables with associated indicators and measures are illustrated in Table 1 as per the questionnaire survey. 
Table 1: Operationalization of variables

\begin{tabular}{|c|c|c|}
\hline Concept & Variable & Indicator \\
\hline \multirow{5}{*}{$\begin{array}{l}\text { Audit } \\
\text { Committee } \\
\text { Attributes }\end{array}$} & $\begin{array}{l}\text { a. Independence } \\
(\mathrm{IN})\end{array}$ & $\begin{array}{l}\text { Ability of expressing views independently and } \\
\text { challenging the management team }\end{array}$ \\
\hline & $\begin{array}{l}\text { b. Knowledge } \\
\text { and } \\
\text { experience } \\
\text { (KE) }\end{array}$ & $\begin{array}{l}\text { Audit committee members' knowledge on the } \\
\text { entity's business, accounting and/or auditing and } \\
\text { experience serving on an audit committee }\end{array}$ \\
\hline & $\begin{array}{l}\text { c. Authority and } \\
\text { resources(AR) }\end{array}$ & $\begin{array}{l}\text { Audit committee members' understanding of their } \\
\text { responsibilities and devoting time and effort the } \\
\text { Committee's affairs }\end{array}$ \\
\hline & d. Diligence (DI) & $\begin{array}{l}\text { Audit committee's adequate authority to perform its } \\
\text { responsibilities and access to relevant information }\end{array}$ \\
\hline & e. Meetings(M) & $\begin{array}{l}\text { Audit committee's meeting arrangements (e.g. } \\
\text { frequency, timing, duration, venue and format) and } \\
\text { agenda }\end{array}$ \\
\hline \multirow[t]{5}{*}{$\begin{array}{l}\text { Effectiveness } \\
\text { of audit } \\
\text { committees }\end{array}$} & $\begin{array}{l}\text { a. Role in } \\
\text { Financial } \\
\text { Reporting (FR) }\end{array}$ & $\begin{array}{l}\text { Reviewing the preparation of the financial } \\
\text { statements and ensuring necessary resources for } \\
\text { financial reporting systems }\end{array}$ \\
\hline & $\begin{array}{l}\text { b. Role in } \\
\text { External } \\
\text { Auditing (EA) }\end{array}$ & $\begin{array}{l}\text { Assessing the external auditor, the audit plan, key } \\
\text { audit issues, problem and reviewing the external } \\
\text { auditor's findings }\end{array}$ \\
\hline & $\begin{array}{l}\text { c. Role in } \\
\text { Internal } \\
\text { Auditing (IA) }\end{array}$ & $\begin{array}{l}\text { Reviewing the internal audit plans, audit reports and } \\
\text { ensuring resources for internal auditing }\end{array}$ \\
\hline & $\begin{array}{l}\text { d. Role in Risk } \\
\text { Management } \\
\text { (RM) }\end{array}$ & $\begin{array}{l}\text { Reviewing the risk management procedure, risk } \\
\text { assessment and risk management }\end{array}$ \\
\hline & $\begin{array}{l}\text { e. Role in } \\
\text { Internal } \\
\text { Control (IC) }\end{array}$ & $\begin{array}{l}\text { Regular monitoring the internal control systems and } \\
\text { ensuring the internal control with regard to all } \\
\text { functions }\end{array}$ \\
\hline
\end{tabular}

Source: Developed by researchers based on Code of Best Practice on Audit Committees, 2002 and Mohiuddin, 2012

Peradeniya Management Review - Vol. I , No.01 , (June)2018 


\section{Data Analysis}

Frequency distributions were used to examine and evaluate the current audit committee practices and effectiveness in order to investigate the contributory factors affecting the effectiveness of audit committees of listed companies in Sri Lanka. A multiple regression model has been run using the questionnaire survey data. Correlation analysis has also used to identify the relationships among variables.

Further, the multicollinearity of the regression model has been investigated using the Variance Inflation Factors (VIFs). The heteroscedasticity of the regression model has been investigated using White's General Heteroscedasticity Test which is an estimator for heteroscedasticity - consistent standard errors. The model specification of the regression model has been investigated using the Ramsey Regression Equation Specification Error Test (RESET) which is a general specification test for the linear regression models. To analyze the statistical test results, the study has assumed a 5 percent level of significance (a probability or p level of 0.05 or 95 percent confidence level).

\section{Results and Discussion \\ Frequency Distribution of Questionnaire Survey Data}

The purpose of analyzing the questionnaire survey data is to examine and evaluate the current audit committee practices and effectiveness of listed companies in Sri Lanka. The frequency of responses toward the statements included in the questionnaire is tabulated. The study summarized the responses for the purpose of reporting and analysis, where "strongly disagree" and "disagree" columns have been added to "disagree" and similarly, "strongly agree" and "agree" columns have been added to "agree" (Table 2). 
Table 2: Frequency (in Percentage) Distribution of Responses toward the Statements on Audit Committee Practices in Sri Lanka

\begin{tabular}{|c|c|c|c|}
\hline & Disagree & Neutral & Agree \\
\hline \multicolumn{4}{|l|}{ Audit Committee Attributes } \\
\hline Independence & - & 1.65 & 98.35 \\
\hline Knowledge and Experience & 10 & 8.35 & 81.65 \\
\hline Diligence & 3.3 & 10.05 & 86.65 \\
\hline Authority and Resources & - & 5 & 95 \\
\hline Meetings & - & 3.3 & 96.7 \\
\hline \multicolumn{4}{|c|}{ Effectiveness of Audit committee: Audit Committee Roles and Responsibilities } \\
\hline Role in Financial Reporting & 6.7 & 7.7 & 85.56 \\
\hline Role in External Auditing & 6.65 & 6.65 & 91.13 \\
\hline Role in Internal Auditing & - & 6.66 & 93.33 \\
\hline Role in Risk Management & 1.1 & 20 & 78.9 \\
\hline Role in Internal Controls & - & 23.3 & 76.7 \\
\hline
\end{tabular}

Source: Survey Data, 2014

All the attributes, namely independence of the members, knowledge and experience, diligence, authority and resources, and meetings seem performing over 80 percent satisfactory level. Effectiveness of audit committee measures towards the roles and responsibilities such as financial reporting, external auditing and internal auditing currently perform as important roles when compared to risk management and internal controls. Overall practices of Audit committees are also perceived to be at a satisfactory level.

\section{Analysis of Regression Statistics}

The objective of analyzing regression statistics is to investigate the contributory factors affecting the effectiveness of audit committees of the listed companies in Sri Lanka (Table 3). 
Table 3: Regression Model for Audit Committee Attributes on Effectiveness of Audit Committees

\begin{tabular}{|c|c|c|c|c|}
\hline Model & Constant & $\beta-K E$ & $R$ & R Squared \\
\hline Summary & -7.230435 & 0.82248 & 0.7526 & 0.5665 \\
\hline ANOVA & $F(5,24)$ & $d f 1$ & $d f 2$ & $\begin{array}{l}\text { Significance } \\
\text { Prob }>F\end{array}$ \\
\hline Sum mary & 6.27 & 5 & 24 & $0.0007 * * *$ \\
\hline \multirow{7}{*}{ Coefficient } & Variable & $\beta$ (Coefficient) & t-value & Significance \\
\hline & IN & 0.1790511 & 0.33 & 0.746 \\
\hline & $\mathrm{KE}$ & 0.82248 & 2.24 & $0.035 * *$ \\
\hline & $\mathrm{DI}$ & 0.018417 & 0.06 & 0.950 \\
\hline & $A R$ & 0.1569153 & 0.97 & 0.343 \\
\hline & $M$ & 0.4379594 & 1.13 & 0.269 \\
\hline & Constant & -7.230435 & -4.71 & $0.000 * * *$ \\
\hline
\end{tabular}

Source: Survey Data, 2014

$* * *$ Significance at $1 \%$ level **Significance at $\mathbf{5 \%}$ level

*Significance at $10 \%$ level

Table 3 depicts that the model is significant $(p$-value $<0.05)$ and about 56.65 percent of the variation of effectiveness of audit committees can be explained using the independent variables of audit committee attributes ( $R$ Squared is $0.5665)$.

The model explains that the Knowledge and Experience (KE) of the audit committee members have positive impacts on the effectiveness of audit committees ( $p$-value $<0.05$ ) and 82.25 percent of the score in Knowledge and 
Experience of the audit committee members is added with the constant in evaluating the effectiveness of audit committee. This finding is connected with the studies undertaken by Beasley and Salterio (2001), DeZoort and Salterio (2001), McDaniels et al. (2002), Bedard et al. (2004) and Bedard and Gendron (2010), who highlighted the significance of Knowledge and Experience of audit committee members.

Although the other variables (independence- IN, authority and resources- AR, diligence- $\mathrm{Gl}$ and meeting-M) do not have significant impact on the effectiveness of audit committee role ( $p$-value $>0.05$ ), independence, and meetings of audit committee have strong positive correlations with effectiveness of audit committees. Table 4 summarizes the bi-variant correlation between audit committee attributes and effectiveness of audit committees.

Table 4: Analysis of the Correlations between Audit Committee Attributes and Effectiveness of Audit Committees

\begin{tabular}{|l|l|l|l|l|l|l|}
\hline & IN & KE & DI & AR & M & RR \\
\hline IN & 1 & $.673^{* *}$ & $.723^{* *}$ & .176 & $.532^{* *}$ & $.698^{* *}$ \\
\hline KE & $.673^{* *}$ & 1 & $.418^{*}$ & .062 & $.667^{*}$ & $.640^{*}$ \\
\hline DI & $.723^{* *}$ & $.418^{*}$ & 1 & .073 & $.396^{* *}$ & $.402^{*}$ \\
\hline AR & .176 & .062 & .073 & 1 & .285 & .299 \\
\hline M & $.532^{* *}$ & $.667^{* *}$ & $.396^{*}$ & .285 & 1 & $.588^{* *}$ \\
\hline RR & $.698^{* *}$ & $.640^{* *}$ & $.402^{*}$ & .299 & $.588^{* *}$ & 1 \\
\hline
\end{tabular}


Most of the independent variables of regression model are correlated (see Table 4). Therefore, the Variance Inflation Factors (VIFs) statistics have been used to investigate the multicollinearity problem of the regression models. The results (VIFs $<10)$ indicate that the models are reasonably free from any multicollinearity problem since VIFs of model is 2.28 .

White's Heteroscedasticity Test has been used to investigate the heteroscedasticity problem of the regression model. The results indicate that the model is free from any heteroscedasticity as accepting Prob $>$ chi squared for the model is 0.7209

Ramsey Regression Equation Specification Error Test (RESET) has been used to investigate the Model Specification problem of the regression model. The results indicate that the model is free from any Model Specification problem (or there is no omitted variables in model) accepting Prob $>\mathrm{F}$ for the model one is 0.2109.

\section{Conclusions}

International interest in exploring effective corporate governance practices and systems has increased over the past few decades. However, the studies on corporate governance in emerging economies are sparse than in developed economies. Therefore, this research was undertaken to examine the practices and effectiveness of audit committees in strengthening the corporate governance system.

According to the questionnaire survey, all the attributes, namely independence of members, knowledge and experience, diligence, authority and resources and meetings are perceived to be highly satisfactory. Roles such as financial reporting, external auditing and internal auditing are considered important when compared to risk management and internal control roles.

A regression model was used to investigate the main factors affecting the achievements of roles and responsibilities and the effectiveness of audit committees of listed companies in Sri Lanka. Knowledge and experience of the 
audit committee members have positive impacts on the effectiveness of audit committees. Further, independence and meetings of audit committee have strong positive correlations with the effectiveness audit committees. Moreover, the regression models are accepted with no multicollinearity, no heteroscedasticity and no specification errors.

\section{References}

Abbott, L.J., Parker, S., Peter, G.F. \& Rama, D.V. (2007). Corporate Governance, Audit Quality, and the Sarbanes-Oxley Act: Evidence from Internal Audit Outsourcing. The Accounting Review. 82(4): 803-835.

Blue Ribbon Committee (BRC). (1999). Report and Recommendations of the Blue Ribbon Committee on Improving the Effectiveness of Corporate Audit Committees. The Business Lawyer. 54(3): 1067-1095.

Bonner, S. \& Lewis, B. (1990). Determinants of Auditor Expertise. Journal of Accounting Research. 28(3): 1-20.

Burke, F.M, Guy, D.M. \& Tatum, K.W. (2002). Audit Committee Responsibility for Internal Control. The Corporate Board. 22(130): 11-17.

Carcello, J.V. \& Neal, T.L. (2000). Audit Committee Composition and Auditor Reporting. The Accounting Review. 75(4): 453-467.

Code of Best Practices on Corporate Governance. (1997). The Institute of Chartered Accountants of Sri Lanka - ICASL).

Code of Best Practice on Audit Committees. (2002). The Institute of Chartered Accountants of Sri Lanka - ICASL).

Code of Best Practices on Corporate Governance. (2003). The Institute of Chartered Accountants of Sri Lanka - ICASL). 
Code of Best Practices on Corporate Governance, 2008 (The Institute of Chartered Accountants of Sri Lanka - ICASL, and the Securities Exchange Commission-SEC, Sri Lanka).

Code of Best Practice on Corporate Governance, 2013 (The Institute of Chartered Accountants of Sri Lanka - ICASL, and the Securities Exchange CommissionSEC, Sri Lanka).

Davidson, W.N., Xie, B. \& Xu, W. (2004). Market Reaction to Voluntary Announcements of Audit Committee Appointments: The Effect of Financial Expertise. Journal of Accounting and Public Policy. 23(4): 279-91.

Gendron, Y., Bedard, J. \& Gosselin, M. (2004). Getting Inside the Blackbox: A Field Study of Practices in Effective Audit Committee. Auditing: Journal of Practice and Theory. 23(1): 153-171.

Gendron, Y. \& Bedard, J. (2006). On the Constitution of Audit Committee Effectiveness. Accounting, Organizations and Society. 31(3): 211-39.

Guideline for Best practice on the "Role of Auditors", 2004 (the Securities Exchange Commission - SEC)

Haron, H., Jantam, M. \& Eow, G.P. (2005). Audit Committee Compliance with KSE Listed Requirements. International Journal of Auditing. 9: 187-200.

Heenetigala, K., 2011. Corporate governance practices and firm performance of listed companies in Sri Lanka. Doctoral dissertation, Victoria University.

Kalbers, L.P. \& Fogarty, T.J. (1993). Audit Committee Effectiveness: An Empirical Investigation of the Contribution of Power. Auditing: Journal of Practice and Theory. 12(1): 24-49.

Lee, T. \& Stone, M. (1997). Economic Agency and Audit Committee: Responsibilities and Membership Composition. International Journal of Auditing. 1:97-116. 
Lin, Z.J., Xiao, J.Z. \& Tang, Q. (2008). The Roles, Responsibilities and Characteristics of Audit Committee in China. Accounting, Auditing \& Accountability Journal. 21(5): 721-751.

Listing Rules. (2008). Colombo Stock Exchange, Sri Lanka.

Mallin, C.A. (2010). Corporate Governance, ( $3^{\text {rd }}$ eds). Oxford University Press: Oxford.

McDaniel, L., Martin, R.D., Maines, L.A. \& Peecher, M.E. (2002). Evaluating Financial Reporting Quality: The Effect of Financial Expertise vs. Financial Literacy. The Accounting Review. 77: 139-167.

Mohamad, S. \& Sori, Z.M. (2001). The Roles of Audit Committees in Supporting a Disclosure Based Corporate Environment: Some Comments. Akauntan Nasional: Journal of Malaysian Institute of Accountants, 14(5): 8-11

Mohiudin, Md. \& Karbhari, Y. (2010). Audit Committee Effectiveness: A Critical Literature Review. AIUB Journal of Business and Economics. 9(1): 97-125.

Mohoudin, Md. (2012). An Empirical Investigation into Audit Committee Practices in Bangladesh: The Case of Companies Listed on the Dhaka Stock Exchange (DSE): Doctoral dissertation, Cardiff Business School, Cardiff University.

Osma, B.G. \& Noguer, B.G. (2007). The Effect of the Board Composition and Its Monitoring Committees on Earnings Management: Evidence from Spain, Corporate Governance: An International Review. 15(6):1413-1428.

Pomeranz, F. (1997). Audit Committees: Where Do We Go From Here. Managerial Auditing Journal. 12(6): 281-284.

Sori, Z.M., Hamid, M.A.A., Saad., S.S.M. \& Evans, J.G. (2007). Audit Committee Authority and Effectiveness: The Perceptions of Malaysian Senior Managers. International Research Journal of Finance and Economics. 8:41-56. 
Spira, L.F. (2002). Audit Committee, Performing Corporate Governance. Kluwer Academic Publishers, Boston, MA.

Treadway Commission. (1987). Report of the National Commission on Fraudulent Financial Reporting. National Commission on Fraudulent Financial Reporting: USA. 